\title{
REMARKS ON TRADE USAGES AND BUSINESS PRACTICES IN INTERNATIONAL SALES LAW
}

\author{
Leonardo Graffi ${ }^{*}$
}

\section{INTRODUCTION}

Trade usages and business practices are key elements of international commerce. In their day-to-day activities, traders and business people around the world constantly rely upon trade usages and business practices across a variety of industries. Usages and practices tend to be dignified by the business community with a status equivalent to that of actual law. As a matter of fact, many business persons often tend to regard trade usages and business practices as very powerful tools to ensure the stability of their bargain and, at times, transact business solely based on such usages and practices, without any written contract. Due to the importance of this subject, distinguished international legal commentators have often attempted to define trade usages and business practices and, in doing so, they have indeed succeeded at providing a substantial amount of theoretical ammunition for the benefit of the interpreter. ${ }^{1}$ What is more challenging, in my opinion, is to understand the

* Attorney-at-law, Freshfields Bruckhaus Deringer LLP (admitted to the bars of Rome, Italy and New York, U.S.A.); J.D., University of Bologna (honours); LL.M. (Harvard Law School). The opinions expressed in this article are the private views of the author, and are not to be construed as the official views of Freshfields Bruckhaus Deringer LLP. The author wishes to thank Professor Franco Ferrari for his guidance.

1. The legal literature discussing trade usages and business practices is virtually endless. For selected articles concerning the meaning of usages and practices in the context of the CISG, see WILHELMAlbrecht Achilles, Kommentar zum UN-Kaufrechtsübereinkommen (CISG) art. 9, ๆ 2 (2000); Stephen Bainbridge, Trade Usages in International Sales of Goods: An Analysis of the 1964 and 1980 Sales Convention, 24 Va. J. Int'L L. 619 (1984); Massimo C. Bianca \& Michael J. Bonell, Commentary on the International Sales Law, art. 9, cmt. 1.2 (1987); E. Allan Farnsworth, Unification of Sales Law: Usage and Course of Dealing, in Unification and Comparative Law in Theory and Practice: Liber amicorum Jean Georges Sauveplanne 81 (1984); Franco Ferrari, La rilevanza degli usi nella convenzione di Vienna sulla vendita internazionale di beni mobili, 10 CONTRATTO E IMPRESA 239 (1994); Franco Ferrari, Relevant trade usage and practices under UN sales law, 5 THE European Legal Forum 273 (2002); Franco Ferrari, Trade Usage and Practices Established between the Parties under the CISG, 5 INT'L Bus. L J. 576 (2003); Clayton P. Gillette, Harmony and Stasis in Trade Usage for International Sales, 39 VA. J. INT'L L. 707 (1999); Aleksandar Goldstajn, Usages of Trade and Other Autonomous Rules of International Trade According to the UN (1980) Sales Convention, in International Sale of Goods: Dubrovnik Lectures 55 (Petar Sarcevic \& Paul Volken eds., 1986); 
interplay (and the related legal and commercial consequences) arising from the application of trade usages and business practices alongside the black letter rules of international conventions and model law instruments, which often refer to usages and practices without defining them.

More specifically, the United Nations Convention on Contracts for the International Sale of Goods (hereinafter "CISG" or "Convention") ${ }^{2}$ expressly deals with trade usages and business practices under Article 9 CISG. Unfortunately, the case law interpreting this provision has only rarely dealt with the issue in an exhaustive and satisfactory manner. As pointed out by one leading commentator: "Only some aspects - albeit important ones-have actually been addressed in the various judgments [relating to Article 9 CISG]."

The interpretation of international sale contracts governed by the CISG is therefore subject to the existence, application and interpretation of trade usages and commercial practices, which are powerful tools for the conduct and development of international commerce. The CISG does not, however, explain how to handle such tools and eventually the usages and practices may be found to conflict with the relevant provisions of this uniform treaty. This

Rolf Herber \& Beate Czerwenka, Internationales Kaufrecht: Kommentar zu dem Über-einkommen der Vereinten Nationen vom 11 April 1980 über Verträge über den internationalen Warenkauf art. 9, $\uparrow 1$ (1991); Von Volker H. Holl \& Oliver Keßler, "Selbstgeschaffenes Recht der Wirtschaft" und Einheitsrecht - Die Stellung der Handelsbräuche und Gepflogenheiten im Wiener UN-Kaufrecht, 6 RECHT DER INTERNATIONALEN WirTSCHAFT 457 (1995); John O. HONNOLd, Uniform LAW FOR INTERNATIONAL Sales Under the 1980 United Nations Convention 175 (2d ed. 1991); Werner Melis, in Kommentar zum UN-Kaufrecht, art. 9, \ 1 (Heinrich Honsell ed., 1997); Karl Neumayer \& Catherine Ming, Convention de Vienne sur les contrats de vente internationale de marchandises Cedidac: Lausanne, art. 9, cmt. 1 (1993); Charalambos Pamboukis, The Concept and Function of Usages in the United Nations Convention on the International Sale of Goods, 25 J.L. \& CoM. 107 (2006); SoERGEL, LÜDERITZ \& LorenZ, Bürgerliches Gesetzbuch mit Einführungsgesetz und Nebengesetzen, vol. 13, Übereinkommen der Vereinten Nationen über Verträge über den internationalen Warenkauf (CISG) (2000); JULIUS voN Staudinger \& Ulrich Magnus, Kommentar zum Bürgerlichen Gesetzbuch mit

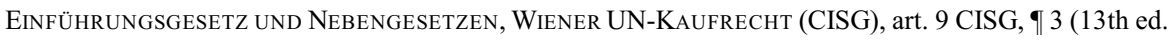
1999) (J. von Staudingers Kommentar zum Bürgerlichen Gesetzbuch mit Einführungsgesetz und Nebengesetzen - Wiener UN-Kaufrecht (CISG) 12th Edition, Sellier-de Gruyter, Berlin 2005); Gregory C. Walker, Trade Usages and CISG: Defending the Appropriateness of Incorporating Custom into International Commercial Contracts, 24 J.L. \& Coм. 263 (2005).

2. This appears to be the most commonly used abbreviation; in this regard. See AXEL FlesSNER \& Thomas KAdNer, CISG? Zur Suche nach einer Abkürzung für das Wiener Übereinkommen über Verträge über den internationalen Warenkauf vom 11, in ZeITSChrift Fur Europaisches Privatrecht 347 (1995).

3. See Ferrari, Relevant trade usage and practices under UN sales law, supra note 1, at 273. See also Gillette, supra note 1, at 715 ("Custom is inherently vague — some call it fuzzy — so that its formal elaboration by courts (as opposed to informal application through extralegal procedures") is often doomed to misstate the actual practice of transactors.). 
paper does not purport to address all the possible ramifications arising from the interplay between trade usages and business practices and the CISG, but rather intends to lay out an analysis of certain selected usages and practices which are commonly found to apply in the case law and have a practical impact on international sale transactions governed by the CISG.

\section{Defining the Scope of Article 9 CISG}

\section{Trade Usages}

The key provision for the analysis of trade usages and business practices under the CISG is Article 9, which states that:

(1) The parties are bound by any usage to which they have agreed and by any practices which they have established between themselves.

(2) The parties are considered, unless otherwise agreed, to have impliedly made applicable to their contract or its formation a usage of which the parties knew or ought to have known and which in international trade is widely known to, and regularly observed by, parties to contracts of the type involved in the particular trade concerned.

It is a well known fact that this provision gave rise to much debate among the drafters during the Vienna Conference. ${ }^{4}$ Article 9 sets out the framework for the interpretation of usages and practices applicable to the international sale contracts governed by the CISG. ${ }^{5}$ In doing so, Article 9 CISG makes a clear distinction between usages and practices. In a nutshell, on the one hand, when referring to usages, the Convention intends to deal with a broad concept that embraces at least those business conducts that are routinely adopted by a certain group or category of business players, taken as a whole. On the other hand, the concept of practices is narrower and by its nature relates to certain behaviours established among the same parties involved in specific series of transactions through repeated courses of dealings.

This being said, one cannot avoid noticing that the CISG does not define a "usage." This prompts the interpreter to ensure that the concept of usages

4. See Official Records: Documents of the Conference and Summary Records of the Plenary Meetings and of the Meetings of the Main Committees (Vienna, 10 Mar.-11 Apr. 1980), U.N. Doc. A/Conf.97/19, New York (USA), 1981 (cited: O.R.) at 89, 262 et seq.; BiANCA \& Bonell, supra note 1, at art. 9, cmt. 2.3.

5. See Holl \& Keßler, supra note 1.

6. For this kind of remarks, see Bianca \& Bonell, supra note 1, at art. 9, cmt. 3.1; Diez-Picazo \& Calvo Caravaca, La compraventa internacional de mercaderías. Comentario de la Convención de Viena, art. 9, at 140 (1998); Jorge Adame Goddard, El Contrato de Compraventa Internacional 80 
(similarly to many other concepts dealt with by the CISG) be autonomously interpreted, ${ }^{7}$ without recourse to specific concepts of national law or to particular national concepts or perceptions. ${ }^{8}$ For instance, the concept of usage commonly used under Italian law requires that the parties believe that the usage is legally binding (the so-called opinio iuris atque necessitatis). ${ }^{9}$ This, however, is not necessary for the purposes of a usage under the CISG, since the parties may decide to comply with a usage on a customary basis even though they are aware that such usage is not legally binding upon them. ${ }^{10}$

Under Article 9(1) CISG the parties are bound by any usage to which they have agreed. As pointed out by Professor Ferrari: "it is not necessary that the agreement be made explicitly; the agreement by which the usages become relevant may also be implicit, as long as there is a real consent, which can also take place after conclusion of the contract." 11

It should be noted, however, that so long as the parties have agreed to apply the usages to their transaction, in accordance with the party autonomy

(1994); Goldstajn, supra note 1, at 96; Melis, supra note 1, at art. 9, ๆ 1; Helga Rudolph, Kaufrecht der Export und Import Verträge, Kommentierung des UN-Übereinkommens über Internationale Warenkaufverträge mit Hinweisen für die Vertragspraxis, art. 9, \2 (1996); Peter Schlechtriem \& Ingeborg Schwenzer, Kommentar zum Einheitlichen UN-Kaufrecht (CISG), art. 9, ๆ 8 (3d ed. 2000).

7. See Bianca \& Bonell, supra note 1, at art. 9, cmt. 3.2; Bianca \& Bonell, supra note 1, at 386; Diez-Picazo \& Calvo Caravaca, supra note 6, at art. 9, 140; Ferrari, Vendita internazionale di beni mobili., arts. 1-13. Ambito di applicazione. Disposizioni generali, at 187 (1994); Herber \& Czerwenka, supra note 1 , at art. 9, \4; Melis, supra note 1, at art. 9, $\{3$.

8. See Franco Ferrari, Besprechung von Magnus, Wiener UN-Kaufrecht, Praxis Des Internationalen Privat - und Verfahrensrechts 64, 65 (1995); Vincent Heuzé, La vente internationale de MARChANDISES - DROIT UNIFORME, cmt. 95 (2d ed. 2000); Melis, supra note 1, at art. 7, ๆ 5; Peter Schlechtriem, Internationales UN-Kaufrecht 43 (1996); Paolo Torzilli, The Aftermath of MCCMarble: Is This the Death Knell for the Parol Evidence Rule?, 74 St. John's L. Rev. 843, 859 (2000); in the case law, see Oberlandesgericht Karlsruhe [Appellate Court] Germany, 25 June 1997, available at http://www.cisg.law.pace.edu/cases/970625g1.html (stating that German legal terms such as mistake [Fehler] and "warranted characteristics" [zugesicherte Eigenschaften] are not transferable to the CISG); Gerichtspräsident Laufen, 7 May 1993, Unilex (stating that the CISG should be interpreted autonomously and not from the respective national law viewpoint held by the individual applying the law).

9. See Galgano, Diritto civile e commerciale, vol. I, 69 (4th ed. 2004) (defining usages as a "fonte non scritta e non statuale di produzione di norme giuridiche: consistono nella pratica uniforme e costante di dati comportamenti seguita con la convinzione che quei comportamenti siano giuridicamente obbligatori (opinio iuris atque necessitatis)"). As pointed out by Gillette, supra note 1, at 707, there is

a compelling rationale on which to elevate custom to the status of legal rule. Requiring adherence to custom not only protects the expectations of parties who are aware of the practices of the trade and anticipate compliance by other in same trade; it also minimizes the risk related to judicial construction of contractual obligations or reliance on state-supplied defaults that do not fit the needs of specific industries.

10. See Schlechtriem \& Schwenzer, supra note 6 , at art. 9,93 , holding that it is not necessary for the purposes of Article 9 CISG that the relevant commercial circles believe that the usages are binding.

11. See Ferrari, Relevant trade usage and practices under UN sales law, supra note 1, at 273. 
rule $^{12}$ any local, regional or national usages (and not just international usages) may come into play. ${ }^{13}$

Thus, there is no doubt that the usages agreed upon by the parties prevail over the provisions of the Convention, as confirmed by the case law. ${ }^{14}$ Ultimately, commercial players often prefer to incorporate by reference in their agreements established trade usages with which they are familiar, rather than negotiating long and detailed contractual provisions that may achieve the same result.

Hence, if it is determined that the usages are applicable and that their choice by the parties is a valid agreement under the applicable national law, ${ }^{15}$ the usages will prevail over the provisions of the CISG. ${ }^{16}$

Article 9(2) adds further relevance to the application of usages to contracts governed by the CISG, since it enables such usages to apply even if the parties have not expressly incorporated them in their agreements. ${ }^{17}$ This provision includes two prongs: (a) a subjective one and (b) an objective one. The subjective prong essentially states that, unless otherwise agreed, the

12. See, e.g., China International Economic and Trade Arbitration Commission 9 Jan. 2008, available at $\mathrm{http}: / /$ cisgw3.law.pace.edu/cases/080109c1.html (holding that: "The parties agreed in the Contract that Incoterms were applicable as international usages. The Tribunal notes that in accordance with the principle of autonomy, Incoterms applied to the present case.").

13. See Achilles, supra note 1 , at art. 9, 4. For this conclusion, see Oberster Gerichtshof [Supreme Court] Austria, 21 Mar. 2000, available at http://www.cisg.law.pace.edu/cases/000321a3.html (holding that usages under Article 9 do not need to be internationally applicable).

14. See, e.g., Oberster Gerichshoft [Supreme Court] Austria, 21 Mar. 2000, available at http://www.cisg.law.pace.edu/cases/000321a3.html; Landgericht Saarbrücken [District Court] Germany, 13 Jan. 1992, available at $\mathrm{http}: / / w w w . c i s g . l a w . p a c e . e d u / c a s e s / 920323 \mathrm{~g} 1 . \mathrm{html}$.

15. It is well known that the CISG does not govern issues of validity in respect of contract formation. Thus, under the CISG the validity of a contract must be assessed based on applicable domestic law, see Helen Hartnell, Rousing the Sleeping Dog: The Validity Exception to the Convention on Contracts for the International Sale of Goods, 18 YALE J. INT'L L. 1, 44-45 (1993).

16. See GodDARD, supra note 6, at 81; Enderlein, Maskow \& Strohbach, Internationales Kaufrecht, art. 9, 1.2 (1991); Ferrari, supra note 7, at 192; Herber \& Czerwenka, supra note 1, at art. 9, \6; Melis, supra note 1, at art. 9, $\uparrow$ 6; Plantard, Un nouveau droit uniforme de la vente internationale: La Convention des Nations Unies du 11 avril 1980, J.D.I. 311, 317 (1988); Rudolph, supra note 6, at art. 9, ๆ 1; Schlechtriem \& Schwenzer, supra note 6, at art. 9, $₫ 2$; for the same view, expressly stated in case law, see Oberster Gerichtshof [Supreme Court] Austria, 21 Mar. 2000, available at http://www.cisg.law.pace.edu/ cases/000321a3.html.

17. This view is confirmed by the case law. See St. Paul Guardian Ins. Co. v. Neuromed Medical Sys. \& Support, GmbH, 2002 U.S. Dist. Lexis 5096 (S.D.N.Y. Mar. 26, 2002). According to Marco Torsello, Commercial Features of Uniform Commercial law Conventions. A Comparative Study Beyond the 1980 Uniform Sales Law 335, at 35 (2004), the requirement that the parties knew or ought to have known of the usages is bewildering. "Indeed, it seems beyond doubt that whenever interpreting whether a party 'ought to have known' about a usage, the interpreter will do nothing but investigate whether the usage is 'widely known' and 'regularly observed."' 
parties are deemed to have impliedly made applicable to their contract or its formation a usage of which the parties knew or ought to have known. ${ }^{18}$ This means that if the subjective test is met, both parties will be bound by the usage. The objective test requires that the usage be "widely known"19 in international trade, and be regularly observed ${ }^{20}$ by parties to contracts of the type involved in the particular trade concerned. Hence, the subjective and objective prongs essentially rely on the ability of the party that is invoking the existence of the binding usage to prove that such usage exists. Clearly, however, if a party invoking the usage cannot successfully prove its existence, it is unlikely that the usage will apply (unless under the applicable national law of the forum a judge will be entitled to apply the usages ex officio).

\section{Practices Established Between the Parties}

Unlike usages, which typically possess general common features, practices tend to have a narrower scope, since they are the result of specific conducts arising from business relationships and bargains executed by the parties. For the purposes of Article 9(2) of the CISG, practices may relate to a particular commercial behaviour, such as the prompt delivery of replacement machinery parts, which an ICC arbitral tribunal held had become normal practice among the parties. ${ }^{21}$ Another example of an established practice based on the parties' prior dealings is the tolerance of a delayed performance, which according to an arbitral panel of the American Arbitration Association (AAA)

18. Ferrari, supra note 7, at 195; Herber \& Czerwenka, supra note 1, at art. 9, para. 8; Gillette, supra note 1, at 719; Maskow, The Convention on the International Sale of Goods from the Perspective of the Socialist Countries, in La vendita internazionale. La convenzione di Vienna dell'11 aprile 1980, at 39, 58 (1981); Neumayer \& Ming, supra note 1, at art. 9, cmt. 3. In the case law see Court of Arbitration and the International Chamber of Commerce, ICC Arbitral Award No. 8324/1995, available at http://cisgw3 .law.pace.edu/cases/958324i1.html; Zivilgericht Basel [Civil Court] Switzerland, 21 Dec. 1992, available at http://cisgw3.law.pace.edu/cases/921221s1.html.

19. The period of exercise of usages is irrelevant, insofar that usages are widely known and observed regularly; see Honnold, supra note 1, at 120.1; STAUdinger \& MAGnus, supra note 1, at art. 9 CISG, \| 23. See Oberster Gerichtshof [Supreme Court] Austria, 21 Mar. 2000, available at http://www.cisg.law .pace.edu/cases/000321a3.html.

20. See Barbara Berry, S.A. de C.V. v. Ken M. Spooner Farms, Inc., 2006 U.S. Dist. LEXIS 31262 (W.D. Wash. Apr. 13, 2006); District Court for the Western District of Washington [Federal District Court] United States 13 Apr. 2006, available at http://www.cisg.law.pace.edu/cases/060413u1.html (holding that the placement of oral orders for goods followed by invoices with sales terms was commonplace practice among the parties and therefore such behaviour was to be incorporated in the contract by way of Article 9 (2) of the CISG).

21. See Court of Arbitration at the International Chamber of Commerce, Arbitral Award No. 8611/1997, 23 Jan. 1997, available at http://cisgw3.law.pace.edu/cases/978611i1.html. 
was one of the reasons for which the late performance of a party had not amounted to fundamental breach. ${ }^{22}$ As pointed out by various legal commentators, the individual business conduct established by the parties, rather than a general kind of commercial behaviour applicable in a given business sector, is the essential factor that characterises the practice. ${ }^{23}$ This, however, implies that the business relationship has been carried out for a certain defined period of time and that the specific conduct giving rise to the practice has occurred in a number of repeat transactions (even though the CISG does not provide guidance as to how many transactions must have occurred to give rise to the practice). ${ }^{24}$ The case law has stressed that a commercial practice cannot be established merely by way of the parties having entered into two contracts. ${ }^{25}$ And clearly, no practice could be deemed to arise from one single delivery of goods between the parties. ${ }^{26}$ Thus, as pointed out by Professor Ferrari, a judgment of the Austrian Supreme Court was met with some surprise, ${ }^{27}$ as it stated that a party's perception from preliminary discussions (albeit not expressly agreed upon) could be deemed to constitute "practices" within the meaning of Article 9, even if this occurred at the outset of the business relationship.

The fact that parties are bound by those practices that have originated between them in the course of extended business relations is consistent with

22. See International Centre for Dispute Resolution of the American Arbitration Association, United States, 23 Oct. 2007, available at http://cisgw3.law.pace.edu/cases/071023a5.html ("The lapse in time between the contractual shipment periods and the Romanian government's blockage of imports was a matter of weeks or days, depending upon the particular Contract. However, this delay in performance did not amount to a fundamental breach for several reasons. As explained below, first, the parties' prior course of dealing and industry practice allowed for some flexibility in the delivery date - a flexibility that was shown in Buyer's responses here, at least at the onset of the delivery delay.").

23. See Achilles, supra note 1, at art. 9, ๆ 16; BiAnCA \& Bonell, supra note 1, at art. 9, cmt. 2.1.1; Ferrari, supra note 7, at 189; Herber \& Czerwenka, supra note 1, at art. 9, \ 3; Holl \& Keßler, supra note 1, at 457; Melis, supra note 1, at art. 9, 4; Neumayer \& Ming, supra note 1, at art. 9, cmt. 1; Rudolph, supra note 6, at art. 9, \4; Staudinger \& Magnus, supra note 1, at art. 9 CISG, \ 13.

24. For this line of reasoning, see Schlechtriem \& Schwenzer, supra note 6, at art. 9, $\uparrow 7$; see also Schlechtriem \& Schwenzer, supra note 6 , at 96 , which mentions the requirement of a certain continuity and duration of a practice (eine gewisse Häufigkeit und Dauer einer Übung).

25. See Zivilgericht Basel [Civil Court] Switzerland, 3 Dec. 1997, available at http://www.cisg.law .pace.edu/ cases/971203s2.html; but see Amtsgericht Duisburg [Petty Court] Germany, 13 Apr. 2000, available at $\mathrm{http} / / / \mathrm{cisgw} 3$.law.pace.edu/cases/000413g1.html (explicitly stating that a certain duration and continuity does not yet exist in the case of two previous deliveries).

26. See Landgericht Zwickau [District Court] Germany, 19 Mar. 1999, available at http://cisgw3 .law.pace.edu/cases/990319g1.html.

27. See Ferrari, Relevant trade usage and practices under UN sales law, supra note 1, at 275 (referring to Oberster Gerichtshof [Supreme Court] Austria, 6 Feb. 1996, available at http://www.cisg.law .pace.edu/cases/960206a3.html). 
the general principles of good faith underlying the $\mathrm{CISG},{ }^{28}$ as well as the prohibition of venire contra factum proprium. ${ }^{29}$ A factual element of trust, which may not be frustrated, has come into existence between the parties. ${ }^{30}$ Accordingly, for instance, a party cannot contend that the contract makes no specific requirements in respect of notification periods (with which the complaining party has not complied), if existing practices indicate the opposite. Regarding the relationship between commercial practices existing between the parties and any conflicting provisions of the CISG, it is commonly acknowledged that the practices will prevail over the Convention. ${ }^{31}$ Moreover, it is generally accepted among the legal commentators that if the usages agreed upon by the parties were to contradict the practices established between the parties, the agreed upon usages should prevail. ${ }^{32}$ This latter view, however, is not supported by a strong practical argument, since in my view the practices (if arisen through a process that accurately reflects the bargain struck by the parties) tend to be a true expression of the parties' autonomy and real intentions, whereas usages typically arise from general sets of conducts in a specific business sector which the parties may know, and yet not be willing to (fully) comply with. ${ }^{33}$

28. See Melis, supra note 1, at art. 9, $₫ 4$; Schlechtriem \& Schwenzer, supra note 6, at art. 9, $₫ 7$.

29. See ACHILles, supra note 1, at art. 9, \ 16; Diez-Picazo \& Calvo Caravaca, supra note 6, at art. 9, 137; Honnold, supra note 1, at 116; Melis, supra note 1, at art. 9, 4; Rudolph, supra note 6, at art. 9, 9 ; Einheitliches Kaufrecht Praktiker-Kommentar und Vertragsgestaltung zum CISG, art. 9, ๆ 16 (Wolfgang Witz, Hanns-Christian Salger \& Manuel Lorenz eds., 2000).

30. Herber \& Czerwenka, supra note 1, at art. 9, \ 3; HonNold, supra note 1, at 9116.

31. Diez-Picazo \& Calvo Caravaca, supra note 6, at 138; Rudolph, supra note 6, at art. 9, ๆ 1; Staudinger \& Magnus, supra note 1, at art. 9 CISG, $\uparrow 12$; EINHEITLICHES KAUFRECHT, supra note 29, at art. $9, \uparrow 1$.

32. See AchilLES, supra note 1, at art. 9, 8; Diez-Picazo \& Calvo Caravaca, supra note 6, at art. 9, 138; Franco Ferrari, What Sources of Law for Contracts for the International Sale of Goods? Why One Has to Look Beyond the CISG, 25 INT'L REV. L. \& ECON. 333, 335 (2005); Garro \& Zuppi, Compraventa internacional de mercaderías, at 62 (1990); Piltz, Internationales Kaufrecht § 2, \ 177 (1993); Reinhart, UN-Kaufrecht, Kommentar zum Übereinkommen der Vereinten Nationen vom 11. Apr. 1980 über Verträge über den internationalen Warenkauf, art. 9, $₫ 2$ (1991). See also Staudinger \& Magnus, supra note 1, at art. 9 CISG, $\uparrow 15$ (proposing a case-by-case approach).

33. For a decision consistent with this reasoning, see Treibacher Industrie, A.G. v. Allegheny Tech., Inc., 464 F.3d 1265 (11th Cir. 2006); 11th Cir. [Federal Appellate Court] United States, 12 Sept. 2006, available at $\mathrm{http} / / / \mathrm{www} . c i s g . l a w . p a c e . e d u / c a s e s / 060912 \mathrm{u} 1 . \mathrm{html}$ (holding that the meaning of a contract term resulting from practices established between the parties prevail over terms of common usage in the industry). Among the legal commentators, this view is supported by Enderlein, Maskow \& Strohbach, supra note 16 , at art. 9 , cmt. 3 (holding the view that practices should take precedence). 


\section{Applying Trade Usages and Established Practices: The Burden of Proof Issue}

The issue of whether or not trade usages or established practices may apply to an international sales contract governed by the CISG is ultimately a matter of proof. Indeed, there are instances where the parties have expressly agreed to incorporate the trade usages or the practices in their contract, by expressly referring to them. Here, the applicability will not be a controversial issue. However, in litigation matters it is often the case that one party will have an interest in proving that the trade usage or the practice applies (for instance, when the relevant trade usages or practices are more favourable than the actual provisions of the CISG), whereas the other party will claim that it has never agreed to apply the usage, or it was not aware of it or that no practice had been established through repeated business conduct. ${ }^{34}$ This is ultimately a question of fact that must be addressed on a case by case basis and the outcome of which is rather unpredictable. Therefore, it is required that the party willing to rely either on the practice or usage prove the existence thereof, ${ }^{35}$ also by means of oral witnesses, if permitted under the applicable local procedural rules. ${ }^{36}$ As noted by paragraph 9 of the UNCITRAL Digest: "there is no difference in the allocation of burden of proof under Article 9(1) and (2). ${ }^{37}$ This criterion has been supported by the case law interpreting the CISG,${ }^{38}$ which generally holds that the parties are not bound by any practices

34. As pointed out in the UNCITRAL Digest of Case Law on the CISG, art. 9, 9 , U.N. Doc. A/CN.9/SER.C/DIGEST/CISG/9, available at http://daccess-dds-ny.un.org/doc/UNDOC/GEN/V04/ 547/68/PDF/V0454768.pdf?OpenElement ("As for the burden of proof, several courts stated that it is the party alleging the existence of practices established between themselves or usages agreed upon that bears it.").

35. ACHILLES, supra note 1, art. 9 -11; Herber, supra note 1, art. 9, $\uparrow 1$; WITZ, supra note 29, art. 9, 11; Larry A. DiMatteo et al., The Interpretive Turn in International Sales Law: An Analysis of Fifteen Years of CISG Jurisprudence, 24 Nw. J. INT'L L. \& Bus. 299, 364 (2004) (“[P]arties relying upon such provisions bear the burden of proof with respect the [sic] custom or usage, its applicability to the trade at issue, and the intent of the parties to incorporate it in their agreement.").

36. See Geneva Pharm. Tech. Corp. v. Barr Labs., Inc., 201 F. Supp. 2d 236, 281-82 (S.D.N.Y. 2002) (accepting oral evidence of an industry custom and holding that based on such industry custom the contract was sufficiently definite).

37. UNCITRAL Digest of Case Law on the CISG-2008 Revision art. 9, ๆ 13, U.N. Doc. A/CN.9/ SER.C/DIGEST/CISG/9, available at http://www.uncitral.org/pdf/english/clout/digest2008/article009.pdf.

38. On this issue, see, e.g., Tribunale di Vigevano, Italy, 12 July 2000, published in GIURISPRUDENZA ITALIANA 280 (2000). For commentary on this landmark decision of the Italian case law on the CISG, see Franco Ferrari, Tribunale di Vigevano: Specific Aspects of the CISG Uniformly Dealt With, 20 J.L. \& Com. 225, 231-39 (2001); Leonardo Graffi, Overview of Recent Italian Decisions on the CISG, 2001 Eur. Legal F. 240, 240-43. 
or usages that are not proved.$^{39}$ In this regard, it is worth noting, however, that various authors have rejected the view that the burden of proof is an issue regulated by the CISG and they have therefore suggested that national laws should apply to this issue.$^{40}$ However, the better view seems to be the contrary, since the allocation of the burden of proof is an issue that falls (at least implicitly) within the scope of the CISG and should rest upon the aggrieved party, ${ }^{41}$ while it is undisputed that the issue of whether or not the evidence is satisfactory should remain within the boundaries of domestic procedural law. ${ }^{42}$

From a practical standpoint, providing evidence that the parties knew or ought to have known about the existence of a usage and that such usage is "widely known" and "regularly observed" in international trade (as required by Article 9(2)) may be somewhat difficult, especially since the tests surrounding the evaluation of actual knowledge or constructive knowledge are subjective tests, which vary from jurisdiction to jurisdiction. Moreover, establishing if a usage is "widely known" may not be straightforward, considering that in highly technical trade sectors few people tend to have an actual insight as to which usages are truly applicable in that trade and will be unlikely to witness to the existence of a "widely known" usage. Finally, national courts (unlike business people) tend to be ill equipped to identify trade usages specific to a particular business sector, as they often lack the necessary knowledge of the business and judges are likely to fail to grasp the underlying commercial drivers of the parties. ${ }^{43}$

39. See, e.g., Oberlandesgericht Dresden [Provincial Court of Appeal] Germany, 9 July 1998, available at http://cisg3.law.pace.edu (party alleging that recipient's lack of response equals consent in the absence of a response to a letter of confirmation was unable to establish that this was a valid international trade usage); Zivilgericht Basel [Civil Court] Switzerland, 3 Dec. 1997, available at $\mathrm{http}: / / \mathrm{cisg} 3$.law.pace.edu (party alleging that existence of a binding international trade usage, according to which payment by means of direct transfer into the account of the seller is common in the import trade industry, need not prove this if the parties ought to have been aware of this practice).

40. To this effect, see, e.g., Warren Khoo, Article 2, in Commentary on the International SALEs LaW, supra note 1, at 38 .

41. For this type of reasoning, see, e.g., Case No. 8213 of 1995, 11 ICC InT'L Ct. ARB. Bull. 49, 50-51 (2000) ("For the claims based on breach of the Purchase Agreements, the Arbitrator has considered the burden of proof to be on Claimants and for the counterclaim, the burden is on Respondent.").

42. For this view, see Franco Ferrari, The Sphere of Application of the Vienna Sales Convention 28 (1995); Franco Ferrari, Burden of Proof Under the United Nations Convention on Contracts for the International Sale of Goods (CISG), 2000 INT'L Bus. L.J. 665, 665-70; Chiara Giovannucci Orlandi, Procedural Law Issues and Law Conventions, 2000 Uniform L. Rev. 23, 27 ("However, the final determination of whether or not the judge finds the evidence sufficiently convincing should continue to be based on the rules of the lex fori, which are also defined as strictly procedural rules.").

43. For similar remarks, see Gillette, supra note 1, at 719; Pamboukis, supra note 1, at 130 (holding that the application of trade usages and business practices under Article 9 CISG requires judges and arbitrators of high caliber, familiar with the international commercial environment); Walker, supra note 1, 


\section{Selected Trade Usages and Business Practices Interpreted BY THE CISG CASE LAW}

\section{INCOTERMS and the CISG}

INCOTERMS are probably the most widely known sources of codified trade usages. They are set out in a catalogue of rules compiled and periodically updated by the ICC. ${ }^{44}$ These rules are accepted by governments, legal commentators, business players and practitioners worldwide for the interpretation of certain commonly used terms in international trade. The use of INCOTERMS promotes uniformity in international trade, in that it reduces altogether uncertainties arising from diverging interpretations of such terms in multiple jurisdictions. More specifically, INCOTERMS govern four main categories of issues arising from international sales: delivery of the goods, passage of risk, allocation of costs, and customs formalities. ${ }^{45}$ It is well known that these terms may apply to an international sales contract under Article 9(1) CISG, if the parties have agreed to incorporate them by reference in their

at 267 ("Customs, by definition, derive their existence from particular actors in a particular context. However, determining how much of the context from which the custom arises to impute into its definition proves to be less than clear for many courts.").

44. Int'l Chamber of Commerce [ICC], INCOTERMS 2010 Pub. No. 715 (2010); see ICC Official Rules for the Interpretation of Trade Terms, Pub. No. 560 (2000); see also Charles Debattista, INCOTERMS and Documentary Practices, Incoterms 2000: A Forum of Experts, 63-89, ICC Pub. No. 617 (2000); Frèdèric Eisemann, La pratique des incoterms: usages de la vente internationale (3d ed. 1988). $C f$. Bergami, Incoterms 2000 as a Risk Management Tool for Importer, VIndobona J. InT'L Com. L. \& ARB. 273-86 (2006) (describing the relationship between INCOTERMS and the CISG); Yves Derains \& Jacques Ghestin, La Convention de Vienne sur la vente internationale et les incoterms, Actes du Colloque des ler et 2 décembre 1989, LiBRAIRIE GÉNÉRALE DE Droit ET DE JuRISPRUdENCE 171 (1990); Henry Gabriel, The International Chamber of Commerce INCOTERMS 1990: A Guide to the Terms and Their Usage, Vindobona J. InT'L Com. L. \& ARB. 61-70 (1999); Henry Gabriel, The International Chamber of Commerce INCOTERMS 2000: A Guide to their Terms and Usage, Vindobona J. InT'L Com. L. \& ARB. 41-73 (2001); Jan Ramberg, ICC Guide to INCOTERMS (2002) ICC Pub. No. 620, 1999; Jan Ramberg, CISG and INCOTERMS 2000 in Connection with International Commercial Transactions, in SHARING International Commercial LaW across National Boundaries: Festschrift for Albert H. Kritzer on the Occasion of his Eightieth Birthday 394-403 (Camilla B. Andersen \& Ulrich G. Schroeter eds., 2008); Jan Ramberg, To What Extent Do Incoterms 2000 vary Articles 67(2), 68 and 69?, 25 J.L. \& Cом. 219-22 (2006).

45. ICC INCOTERMS Rules (2000), http://www.iccwbo.org/incoterms/id3038/index.html (providing thirteen terms categorized into four groups: E Group: EXW; F Group: FCA, FAS, FOB; C Group: CFR, CIF, CPT, CIP; D Group: DAF, DES, DEQ, DDU, DDP; note also that the updates to INCOTERMS publications have continued to the INCOTERMS 2010, which will come into effect on 1 January 2011). 
agreement. ${ }^{46}$ INCOTERMS may also apply pursuant to Article 9(2), if the subjective and objective tests have been met. In St. Paul Guardian, the Federal District Court of the Southern District of New York ${ }^{47}$ held that "INCOTERMS are incorporated into the Convention through Article 9(2)." Here, the court stated that, pursuant to Article 9(2), the INCOTERMS' definitions should be applied even though the contract did not contain an explicit reference to INCOTERMS. In a nutshell, the parties had made reference in their contract to a CIF term (without expressly mentioning the INCOTERMS). In the opinion of the court, the parties' choice plainly meant that they had intended to refer to the definition of CIF included in the INCOTERMS.$^{48} \mathrm{~A}$ year later, the same conclusion was reached by the Court of Appeals of the Fifth Circuit, ${ }^{49}$ which moved one step further in the analysis. In a controversy arising from a contract between BP Oil International and an Ecuadorian oil company relating to the sale of gasoline, the parties had included in their agreement reference to the fact that gasoline was to be delivered "CFR La Libertad, Ecuador." The Fifth Circuit held that since "CFR" is part of the 1990 INCOTERMS issued by the ICC and the CISG incorporates INCOTERMS through Article 9(2), even if the usage of INCOTERMS is not global, the fact that they are well known in international trade means that they are incorporated through Article 9(2). Similar conclusions have been reached by a Russian arbitral tribunal, ${ }^{50}$ as well as by a decision of the Court of Appeals of Genoa. ${ }^{51}$ A recent decision of a Swiss court went so far to suggest that: "even when the Incoterms were not incorporated into the contract explicitly or implicitly, they are considered as rules of interpretation." ${ }^{52}$ Along the same lines, in China North Chemical Industries the District Court of Texas ${ }^{53}$ ruled that since the international sales

46. See Melis, supra note 1, at art. 9, 97.

47. See St. Paul Guardian Ins. Co. v. Neuromed Med. Sys. \& Support, No. 00 CIV. 9344 (SHS) (S.D.N.Y. Mar. 26, 2002).

48. Id.

49. See BP Oil Int'l, Ltd. v. Empresa Estatal Petroleos de Ecuador, 332 F.3d 333 (5th Cir. 2003).

50. See Tribunal of International Commercial Arbitration at the Russian Federation Chamber of Commerce and Industry (Russia), 6 June 2000, available at http://cisgw3.law.pace.edu/cases/ 000606r1.html (406/1998).

51. See Corte di Appello [Appellate Court] di Genova (Italy), 24 Mar. 1995, available at http://cisgw3.law.pace.edu/cases/950324i3.html (the court interpreted a FOB clause by referring to the INCOTERMS even though the parties had not expressly referenced to the INCOTERMS).

52. Tribunal Cantonal [Higher Cantonal Court] du Valais (Switzerland), 28 Jan. 2009, available at http://cisgw3.law.pace.edu/cases/090128s1.html.

53. China N. Chem. Indus. Corp. v. Beston Chem. Corp., No. Civ. A. H-04-0912, 2006 WL 295396 at *6 (S.D.T.X. Feb. 7, 2006), also available at http://cisgw3.law.pace.edu/cases/060207u1.html. 
contract included a reference to a "CIF" term for delivery of the cargo to Berwick, Louisiana, the CIF term was to be interpreted in accordance with Incoterms 1990, which were in effect when the parties made the contract. The above referenced decisions consistently take the view that a reference in a contract governed by the CISG to certain standard clauses of international trade (such as CIF, FOB, EXW etc.) are to be deemed to constitute an automatic reference to the definition of such clauses under the INCOTERMS. Personally, I take the view that this implied construction of the meaning of such clauses is too simplistic and, as pointed out by certain leading legal commentators, the consent of the parties to the INCOTERMS is not self evident, ${ }^{54}$ "in various countries abbreviations such as Fob, Cif, etc., do not always have the meaning ascribed to them by Incoterms." ${ }^{55}$ As a matter of fact, the use by the parties of a CIF clause should not in all instances be construed as a reference to the same internationally accepted term under INCOTERMS, since if the parties have not referred to INCOTERMS, they may have established a practice between them of giving a specific local interpretation to CIF clauses, which diverges from the international meaning of CIF under INCOTERMS.

\section{CIF Terms and Implicit Reference to INCOTERMS: A Practical Example}

It is well known that shipments designated "CIF" ${ }^{56}$ require the seller to

54. See Achilles, supra note 1, at 14 ; Wolfgang Witz, Hans-Christian Salger, Manuel Lorenz, Einheitliches Kaufrecht [International Uniform SAles Law], art. 9, \16 (2000). But see Jorge Adame Goddard, The International Sale Contract 85 (1994); Bonell \& Bianca, supra note 1, at 3.5, available at http://www.cisg.law.pace.edu/cisg/biblio/bonell-bb9.html; Fritz Enderlein, Dietrich Maskow \& Heinz Strohbach, International Sales Law, Commentary, art. 9, 1.2 (1992), cmt. 11, available at http://cisgw3.law.pace.edu/cisg/biblio/enderlein.html\#art09a; Rolf Herber \& Beate CzerwenK, InTERNATIONALES KaUfRecht, KOMMENTAR ZU DEM ÜBER-EINKOMMEN DER VEREINTEN NATIONEN VOM

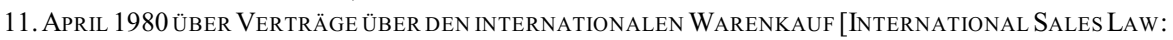
Commentary on the United Nations Convention of 11 April 1980] art. 9, 116 (1991).

55. For this kind of reasoning, see Franco Ferrari, Trade Usage and Practices Established between the Parties under the CISG, 2003 InT'L Bus. L.J. 571, 576 (2003); see also Clayton P. Gillette, Harmony and Stasis in Trade Usages for International Sales, 39 VA. J. INT'L L. 707, 736 (1999).

56. The following explanation of "CIF" is provided in INT'L CHAMBER OF COMMERCE, INCOTERMS 2000: ICC OfFicial Rules for the Interpretation of Trade Terms 65 (1999):

"Cost, Insurance and Freight" means that the seller delivers when the goods pass the ship's rail at the point of shipment. The seller must pay the costs and freight necessary to bring the goods to the named port of destination but the risk of loss or damage to the goods, as well as any additional costs due to events occurring after the time of delivery, are transferred from the seller to the buyer. However, in CIF the seller also has to procure marine insurance against the buyer's risk of loss of 
procure and pay for the costs of transport and insurance of the goods to the destination port, but the transfer of the risk of loss to the buyer takes place once the goods pass the ship's rail at the port of shipment. Also, the INCOTERMS (including the CIF term) are not designed to resolve questions of title or other property rights of the seller and buyer, since these issues are to be resolved by the parties' agreement or by other substantive law that governs the agreement. ${ }^{57}$ Under INCOTERMS 2000, the seller must provide insurance that shall be in accordance with minimum cover requirements. As pointed out by Professor Gabriel, "the minimum cover requirement reflects the common practice of subsequent sales of the goods in transit where it is impossible to know the actual insurance needs of every subsequent buyer." ${ }^{28}$ In a sale of goods contract governed by a CIF INCOTERM clause, the minimum insurance made available by the seller to the buyer must cover the price of the goods sold, plus 10 percent of such price (i.e., 110 percent of the price of the goods sold). ${ }^{59}$ The ICC Guide to INCOTERMS 2000 clarifies that the additional 10 percent purports to cover the minimum resale profit anticipated by the buyer. ${ }^{60}$ It is rather questionable, however, that if the parties merely referred in their contract to a generic "CIF" term, in the absence of any express reference to INCOTERMS, they actually intended to have an insurance coverage equal to 110 percent of the price of the goods sold.$^{61}$ For instance, there may be instances where the CIF clause commonly adopted by shippers or sales people in a certain port of transit does not require (as the INCOTERMS do) that insurance should be provided by the seller with a marked up coverage exceeding by 10 percent the price of the goods sold. Local usages, for instance, may provide for a CIF term that only requires

or damage to the goods during the carriage.

57. See Henry Gabriel, The Int'l Chamber of Commerce INCOTERMS 2000: A Guide to Their Terms and Usage, 5 Vindobona J. 1, 41 n.3, available at http://www.cisg.law.pace.edu/cisg/biblio/ gabriel3.html.

58. Id. at 56 .

59. For a case specifically citing the usage requiring the insurance under CIF terms to cover $110 \%$ of the cost of the goods sold, see Tribunal of International Commercial Arbitration at the Russian Federation Chamber of Commerce and Industry, 13 Apr. 2006, available at http://cisgw3.law.pace.edu/cases/060413r1.html. (1999).

60. See Jan Ramberg, ICC Guide to Incoterms 2000: Understanding ANd Practical Use 121

61. The affirmative view was held by the Tribunal of International Commercial Arbitration at the Russian Federation Chamber. Tribunal of International Commercial Arbitration at the Russian Federation Chamber of Commerce and Industry, 13 Apr. 2006, available at http://cisgw3.law.pace.edu/cases/ 060413r1.html (holding that "on the basis of CIF the minimum insurance must be the price of the goods plus 10 percent"). 
insurance coverage up to the value of the goods sold. This practical example shows that the automatic reference to INCOTERMS when a CIF (or FOB or $\mathrm{EXW}$ ) term is incorporated in a contract may not at all times be consistent with the parties' intention. Hence, the courts should not automatically apply INCOTERMS as a hard and fast rule whenever the parties have referred, say to a "FOB" or "CIF" term. Courts should instead ensure that there is sufficient evidence to support the argument that the parties truly intended to incorporate the INCOTERMS in their contract and, in lack of such evidence, should interpret the parties' true intentions.

\section{3. $U C P$}

The Uniform Customs and Practice for Documentary Credits (hereinafter, "UCP") are a set of rules applicable to the issue and execution of letters of credit. ${ }^{62}$ The UCP are widely adopted and, as pointed out by Professor Schmitthoff almost thirty years ago, "as banks in more than 170 countries operate letters of credit under this document, the Uniform Customs and Practice for Documentary Credits has become world law." ${ }^{93}$ UCP 600 are the latest revision of the Uniform Customs and Practice that govern the operation of letters of Credit and have come into effect on 1 July 2007.

The UCP gather a set of rules applicable to specific transactions in which documentary credits are employed as methods of payment between merchants. The wide use of documentary credits in international trade provides a strong indication of the fact that the principles underlying the UCP are widely known to, and regularly observed by, traders across the five continents. Like INCOTERMS, UCP are the result of long established usages in various industries and are bred in the commercial, not academic, world. In practice, however, it is difficult to understand if the international business community

62. For reference materials on letters of credit, see Richard King, GutTERIDGE AND MEgRAH's Law of Bankers' Commercial Credits (8th ed. 2001); Raymond Jack et al., Documentary Credits. The Law and Practice of Documentary Credits Including Standby Credits and Demand Guarantees (3d ed. 2001); Matti Kurkela, Letters of Credit and Bank Guarantees under International Trade Law (2d ed. 2007); Roeland Bertrams, Bank Guarantees in International Trade (3d ed. 2004); Carole Murray et al., Schmitthoff's Export Trade: The Law and Practice of International Trade (11 th ed. 2007); André Tunc, Réflexions Générales sur la Vente Internationale et Crédits Documentaires, 16 European Transport Law, Belgium 151 (1981); for a discussion of the implications of the UCP rules, see Roberto Bergami, What Can UCP 600 Do for You?, 11 Vindobona J. InT'L Com. LAW \& ARB. 1 (2007). ed. 1981)

63. See Clive M. Schmitthoff, Commercial Law in a Changing Economic Climate 28 (2d 
has embraced UCP in their entirety, or if, instead, merchants have become familiar with certain aspects of UCP and not with the entirety of the various complex granular provisions set forth therein. In my opinion, UCP should only apply to an international sales contract pursuant to Article 9(1) CISG if the parties have expressly referred to them. This view is consistent with and stems directly from the wording of Article $1 \mathrm{UCP}$, which states that: "The Uniform Customs and Practice for Documentary Credits, 2007 Revision, ICC Publication no. 600 ("UCP") are rules that apply to any documentary credit ("credit")... when the text of the credit expressly indicates that it is subject to these rules...."

With respect to payment obligations, it is well known that under the CISG the buyer is required to pay the purchase price for the goods in accordance with the provisions of Articles 53 and 54. Article 54 CISG, provides that:

[t] he buyer's obligation to pay the price includes taking such steps and complying with such formalities as may be required under the contract or any laws and regulations to enable payment to be made.

On the other hand, in a documentary sales transaction the seller has the duty to hand over to the buyer any documents relating to the goods as set out in Articles 30 and 34 CISG. Article 34 of the CISG provides (in part) that:

[i]f the seller is bound to hand over documents relating to the goods, he must hand them over at the time and place and in the form required by the contract.

Although letters of credit are payment instruments which are typically deemed effective and enforceable regardless of any issues or claims arising from the underlying sales contract, ${ }^{64}$ in international agreements governed by the CISG an interplay between the provisions of UCP and those of the CISG itself may often occur in practice. By way of example, the tender of strictly complying documents under clause $16 \mathrm{UCP}$ is an essential requirement to make a payment under a letter of credit and, ultimately, to discharge the payment obligations under the sales contract. Accordingly, the bank is obliged to refuse to pay the price if the documents submitted to it by the buyer do not comply with the terms set out in the letter of credit. This, in turn, means that the seller must hand over to the buyer a complete and accurate set of documents that

64. See Bertrams, supra note 62, at 199 (noting that it is fully accepted that the guarantee has a cause of its own, which is independent from the cause of the underlying contract and that such former cause can be recognized in the will of the parties to provide security in a manner which is independent from the underlying relationship). 
will enable the buyer to request payment from the bank. Depending on the circumstances of the case, the failure by the seller to comply with such an obligation (which ultimately has implications both under UCP and the CISG) may constitute a fundamental breach under the CISG ${ }^{65}$ Clearly, in a scenario where the conduct of the seller must be assessed in order to determine if a fundamental breach has in fact occurred, the express reference to the UCP in the contract will make the difference. Under clauses 14(a) and 14(b) UCP a bank must examine a presentation of documents relating to a letter of credit within five banking days and determine if the presentation is compliant with the terms of the letter of credit. Under clause $16 \mathrm{UCP}$ a bank may refuse to honour the payment obligations if it finds that the documents were not compliant. This standard of review has led Professor Schwenzer to consider that if the contract provides for payment by means of a letter of credit, this implies that the documents need to be "clean" in every respect, otherwise the buyer can avoid the contract. ${ }^{66}$ In other words, the reference to UCP implies that the seller's failure to provide a complete and accurate set of documents will be subject to a stricter scrutiny than if the CISG alone were deemed to apply. Such kind of remark derives from the fact that the buyer may avoid the contract under Article 25 CISG only if a fundamental breach has occurred. Hence, the incorporation by reference of the UCP into the contract means that the seller must comply with a specific set of rules governing documentary credits, which calls for strict compliance with documentary obligations. Article 30 CISG requires the seller to "deliver the goods [and] hand over any documents relating to them." This provision essentially recognises that the contract may impose separate obligations in relation to goods and documents. It is therefore self-evident that in international sale contracts involving letter of credit transactions governed by UCP, the delivery of non-conforming documents can give rise to a fundamental breach, if the result of this breach

65. See 2008 UNCITRAL Digest of Case Law on the United Nations Convention on the International Sale of Goods, Pace Law School Institute of International Commercial Law (June 11, 2009), http://www.cisg.law.pace.edu/cisg/text/digest-art-34.html ("The handing over of nonconforming documents constitutes a breach of contract to which the normal remedies apply. Provided the breach is of sufficient gravity it can amount to a fundamental breach, thus permitting the buyer to declare the contract avoided."); for a commentary on the concept of fundamental breach under Article 25 of the CISG, see Franco Ferrari, Fundamental Breach of Contract under the UN Sales Convention on Contracts for the International Sale of Goods-25 years article 25, 5 RevUe DE Droit des AfFaires Internationales 389 (2005); Leonardo Graffi, Case Law on the Concept of "Fundamental Breach" in the Vienna Sales Convention, 3 Revue de Droit des Affaires Internationales 338 (2003).

66. See Ingeborg Schwenzer, The Danger of Domestic Preconceived Views with Respect to the Uniform Interpretation of the CISG: The Question of Avoidance in the Case of Nonconforming Goods and Documents, Victoria U. Wellington L. Rev. 795, 805 (Apr. 2005). 
is that the bank irrevocably refuses to pay the price for the goods. ${ }^{67}$ This example shows the significance of the interplay between the provisions of UCP and Article 25 CISG and the importance of understanding the practical implications of the interpretation of trade usages under the CISG. As a potential mitigating factor, one must look at clause 16(b) of UCP, under which the issuing bank can decide in its sole judgment to approach the buyer to see if it deems fit to waive the document discrepancies. ${ }^{68}$ Ultimately, if the buyer is satisfied with the delivery of the goods and the discrepancies are minor, he will have no interest in denying the waiver thereof, and such behaviour would be consistent with the principle of good faith underlying the CISG. Yet, the interplay between the provisions of UCP on strict document compliance and the breach under the CISG are worth paying a great deal of attention, since the consequences of the failure to meet the standards provided by UCP can be rather harsh.

\section{Letters of Confirmation: The Issue of Silence}

An issue that frequently arises in the practice of international sales is that of whether or not silence in response to a letter of confirmation may be sufficient to reach an agreement. Traders and business people across the world do not often find it practical to reply in writing to a letter of confirmation ${ }^{69}$

67. For similar conclusions, see Maartje Bijl, Fundamental Breach in Documentary Sales Contracts: The Doctrine of Strict Compliance with the Underlying Sales Contract, Eur. J. Com. ConT. L. at 19, 28 (Jan. 2009) (holding that "[1]etter of credit practice strongly suggests that if the parties have agreed to payment by means of a letter of credit, they have simultaneously agreed to apply the strict compliance principle to the delivery of documents in the underlying sales contract").

68. For a discussion of the issue of discrepancies in letters of credit, see Roberto Bergami, Discrepant Documents and Letters of Credit: The Banks' Obligations Under UCP500, 7 VINDOBOna J. INT'L COM. L. \& ARB. 105 (2003).

69. For a detailed discussion of the issue of commercial letters of confirmation under the CISG, see Michael Esser, Commercial Letters of Confirmation in International Trade: Austrian, French, German and Swiss Law and Uniform Law Under the 1980 Sales Convention, 18 GA. J. INT'L \& Comp. L. 427 (1988), available at http://www.cisg.law.pace.edu/cisg/biblio/esser.html ("Confirmation letters are typically employed where the parties negotiate in different ways, for example, when they exchange letters, negotiate on the telephone, send telexes and fail to reduce their final agreement to writing."). For an example of a specific practice established among pharmaceutical companies, which did not find practical to reply in writing to a letter of confirmation, see Geneva Pharmaceuticals Technology Corp. v. Barr Laboratories, Inc., 201 F. Supp. 2d. 236, 247 (S.D.N.Y. 2002), aff'd in part, rev'd in part and remanded, 386 F.3d 485 (2d Cir. 2004) (where plaintiffs alleged that it is a widespread practice throughout the pharmaceutical industry that a supplier providing a reference letter commits itself to providing commercial quantities of the raw material and that throughout the 1990's it was also practice to rely on informal oral arrangements, rather than written supply contracts (for example, more than $90 \%$ of the bulk pharmaceutical ingredients purchased by Barr, and the majority of bulk pharmaceuticals sold by ACIC/Brantford, did not involve 
and they may prefer to simply rely on prior usages or past commercial practices. It is therefore necessary to determine if under such circumstances silence may amount to consent. Commercial letters of confirmation have been the object of wide discussions among legal commentators and the case law of various European countries for more than a century. ${ }^{70}$ By way of background, a commercial letter of confirmation is typically a document setting out the terms of a contract, which is sent by one party to another party in respect of a contract which has already been concluded orally (e.g., over the telephone) or which has not yet been concluded. As pointed out by Professor Ferrari: "It is safe to assume that the rules pertaining to this issue may be understood as usages within the (autonomous) meaning of the CISG",71 and should not be construed in accordance with the meaning attributed to them under national laws. It is also worth noting that Article 18(1) CISG expressly provides that "[s]ilence or inactivity does not in itself amount to acceptance." This provision may, however, be derogated by an applicable usage or practice, so long as the parameters of either Article 9(1) or 9(2) of the CISG are met. Under Article 9(1), silence can be deemed a binding sign of a party's acceptance if it constitutes a usage to which the parties have agreed or a practice which the parties have established between themselves. In my view, it is rather unlikely that the parties have expressly agreed that silence will constitute a form of agreement, since silence is typically a form of acceptance that will occur in transactions that are not heavily regulated. It is also more frequent in practice that the parties will establish in their business dealings a practice of accepting contracts by way of silent or tacit acceptance. ${ }^{72}$ The existence of the practice needs, however, to be proved by the party invoking it and evidence should be provided that a number of contracts have been concluded through silent acceptance. ${ }^{73}$ If Article 9(1) does not apply, a party

written supply agreements)).

70. See Esser, supra note 69.

71. See Franco Ferrari, Trade Usage and Practices Established between the Parties under the CISG, 2003 INT'L Bus. L.J. 571, 575 (2003); to this effect, see also Michael Esser, Die letzte Glocke zum Geleit?-Kaufmännische Bestätigungsschreiben im Internationalen Handel: Deutsches, Französisches, Österreichisches und Schweizerisches Recht und Einheitliches Recht unter der Kaufrechtskonvention von 1980, 29 Zeitschrift FÜr ReChtsvergleichung 167, 188 (1988); Burghard Piltz, Internationales KAUFRECHT $\S 2$, 178 (1993).

72. See CLOUT Case No. 95 [Des Zivilgerichts des Kantons Basel-Stadt (Civil Court of Basel) Switzerland, 21 Dec. 1992], available at $\mathrm{http}$ ://www.uncitral.org/clout/showDocument.do?documentUid= 1298.

73. For similar remarks, see Joseph Lookofsky et AL., The Draft UNCITRAL Digest and Beyond: CASes, Analysis And UnResolved Issues in the U.N. SAles Convention 196 (Franco Ferrari, Harry Flechtner \& Ronald Brand eds., 2004). Regarding the need to give sufficient evidence of the 
may still be in a position to argue that the silent acceptance constitutes a usage of which the parties knew or ought to have known and which in international trade is widely known to, and regularly observed in the relevant trade sector by, parties to contracts of the type involved in the specific transaction. ${ }^{74}$ However, the majority of the legal commentators and the case law held that for the usage to be effective, the mere fact that the laws of the country in which the recipient has its place of business admit the silent acceptance of a contract may not be sufficient grounds to bind both parties under Article $9(2) \cdot{ }^{75}$ In a Swiss case precedent ${ }^{76}$ where the parties had not entered into a written contract, but the seller had simply delivered a commercial letter to the buyer confirming that a certain quantity of textiles was going to be manufactured and supplied, a Swiss court found that the letters of confirmation sent by the seller and the subsequent failure by the buyer to react reflected a usage as to the formation of contracts in the sense of Article 9(2) CISG. According to the court, the parties had impliedly made that usage applicable to their contract, since they knew or ought to have known the binding nature of such confirmations, which are recognized under both laws of the countries in which the parties had their place of business (i.e., Austrian law and Swiss law).$^{77}$ Proving the existence of a trade usage or commercial

existence of the usages, see, e.g., Landgericht Landshut [District Court of Landshut] Germany, 12 June 2008 , available at $\mathrm{http} / / \mathrm{cisgw} 3$.law.pace.edu/cases/080612g2.html (holding that in a sale of metallic slabs the seller would have had to substantiate that there is a specific trade usage in respect to the sale of metallic slabs between Germany and Italy, which contained the conferral of jurisdiction to the place where the supplier is domiciled or the acceptance of the principles on silence in respect to a commercial order confirmation, but the seller had failed to do so).

74. See Achilles, supra note 1, at 94 ; Holl \& Keßler, supra note 1, at 459; Neumayer \& Ming, supra note 1; SChlechtriem, supra note 1, at 9 29; VON StAUdinger \& MAGNus, supra note 1, at 927.

75. See Oberlandesgericht Frankfurt [Appellate Court of Frankfurt] Germany, 5 July 1995, available at http://cisgw3.law.pace.edu/cases $/ 950705 \mathrm{~g} 1 . \mathrm{html}$. Among the legal commentators, see Ferrari, supra note 71, at 575; Herber et al., supra note 1, at 12 ; for a different opinion, see Carsten Ebenroth, Internationale Vertragsgestaltung im Spannungsverhältnis zwischen AGBG, IPR-Gesetz und UN-Kaufrecht, 1986 ÖSTERREICHISCHES JURISTISCHE BLÄTTER 681, 688 (1986); for a diverging view, however, see Ulrich Huber, Der UNCITRAL-Entwurf eines Übereinkommens über internationale Warenkaufverträge, 43 RABELS ZEITSCHRIFT FÜR AUSLÄNDISCHES UND INTERNATIONALES PRIVATRECHT 413, 449 (1979) (holding that if under the silent party's domestic law silence is recognized as a form of acceptance, than this law should control).

76. See CLOUT Case No. 95 [Des Zivilgerichts des Kantons Basel-Stadt (Civil Court of Basel) Switzerland, 21 Dec. 1992], available at $\mathrm{http} / /$ www.uncitral.org/clout/showDocument.do?documentUid= 1298.

77. Id. See also Franco Ferrari, Trade Usage and Practices Established between the Parties under the CISG, 2003 INT'L Bus. L.J. 571, 575 (2003) (Note that according to Professor Ferrari, the decision of the Civil Court of Basel has failed to take notice of the fact that in "one of the two states involved (namely Austria), the effect of such a letter of confirmation, i.e. the conclusion of a contract, has been ruled out [on 
practice capable of derogating from the rule set out in Article 18(1) CISG may, however, be a difficult task. In a 2007 decision, ${ }^{78}$ a Dutch appellate court was called to interpret a dispute arising from a sale by a Belgian company of a certain machinery to a Dutch company. The invoice sent by the seller indicated that "the goods remain our property until complete payment has been received." The seller also used a set of general conditions, which further confirmed that "delivered goods remain the property of the seller until full payment has been received, meaning in particular that the buyer cannot resell the goods or give them as collateral." However, the purchasing agreement did not state anywhere that the purchase was subject to a reservation of property. The Dutch buyer did not agree to or object against the provision on the invoice reserving property to the Belgian company. However, the Dutch buyer failed to pay the entire purchase price and meanwhile sold the machinery to a third party, leasing it back from that same third party. The Belgian seller claimed that the Dutch buyer had violated the property reservation clause set out in the invoice and the general conditions. However, the Dutch appellate court noted (in my view correctly) that, since there was no evidence that the reservation of property was an established practice or usage by which the Dutch company would be bound and since the Dutch company could only have become aware of the reservation of property after receiving the invoice (regardless of whether the reference to the reservation of property was made on the front or the back thereof), the buyer could not be deemed to have consented to the reservation of property clause. A different position was taken in a case decided by the Court of Appeals of Paris,$^{79}$ in which the French judges ruled out the possibility that the buyer's silence to the confirmation order delivered by the seller and concerning the sale of 100,000 meters of fabric could be deemed to constitute an acceptance. Here, the Court of Appeals held that even though the seller and the buyer had previously developed a practice of transacting business based on confirmation orders silently accepted by the buyer, the new sale dealt with a very different type of fabric (namely, a new lycra-type of fabric) and therefore the seller could not rely on the prior

\footnotetext{
Austrian law, see for instance, OGH (Austria) 26 June 1974, ÖstJB1. (1975) 89]”).

78. See CLOUT Case No. 827 [Hof's-Hertogenbosch (Appellate Court of Hertogenbosch), The Netherlands, 29 May 2007, available at http://cisgw.law.pace.edu/cases/070529n1.html; see also LG Gera, [District Court Germany] Germany, 29 June 2006, available at http://cisgw3.law.pace.edu/cases/ $060629 \mathrm{~g} 1 . \mathrm{html}$ (holding that a contract cannot be assumed on the basis of silence to a letter of acknowledgment — as the court cannot establish such a practice at the seat of the buyer and as the seller failed to prove that there had been such a practice between the parties).

79. See CLOUT Case No. 490 [Cour d'appel de Paris] (Court of Appeal of Paris), France, 10 Sept. 2003.
} 
practice. As a result, the "confirmation of order" was regarded as an offer of sale of goods, which the buyer had not accepted. The position of the French court in the case at hand appears to be rather draconian, since the nature or kind of good sold should not be a key element in determining if a practice has been established among the parties. In other words, if the parties have repeatedly transacted business based on a silent acceptance of confirmation orders, so long as the trade practice and sector remains the same, the type of good sold should not be a decisive factor in determining whether or not the practice falls under Article 9 CISG. Furthermore, in the specific case the difference between the goods sold related only to a different type of fabric, not even to a different type of good overall.

\section{Conclusions}

Since the existence of a usage or practice largely depends upon the specific facts of the case, the issue of whether or not trade usages or practices established among the parties may apply to an international sales contract governed by the CISG pursuant to Article 9 becomes a matter of proof by the party invoking their application. ${ }^{80}$ There are many instances in which the successful application of the usages or practices can provide benefits to a party. For example, a payment delay or a certain quantity of defective goods sold may be tolerated by a party under certain trade usages or business practices, whereas such delays or defects could be deemed to amount to a breach of contract under the applicable provisions of the CISG. It may be possible (at least in theory) that a judge applies trade usages or business practices ex officio, but this is rather unlikely to occur in practice, especially in the absence of specific evidence provided by a party of the transaction. As pointed out by leading commentators, ${ }^{81}$ in arbitration proceedings there are higher chances that a specialized arbitrator may be aware of specific trade usages of a given business sector and decide to apply them on its own motion. To sum up, trade usages and business practices can be successfully invoked by a party, so long as adequate and persuasive evidence is made available to

80. See Pamboukis, supra note 1, at 124-25 ("As with the usages agreed upon by the parties or the practices established between them, the party that alleges the existence of any binding usage has to prove it").

81. See Bianca \& Bonell et AL., supra note 1, at 112 (holding that the application of usages by an arbitrator, by virtue of his office, through various rules of arbitration, is allowed and at times may even be required); Patrick X. Bout, Trade Usages: Article 9 of the Convention on Contracts for the International Sale of Goods (1998) § II(G), http://www.cisg.law.pace.edu/cisg/biblio/bout.html. Pamboukis, supra note 1 , at $124-25$. 
the judge or arbitrator regarding the existence and applicability of the usage or business practice. Yet, it is difficult to predict how a court or arbitration panel will react, since the sufficiency and persuasiveness of evidence is a procedural issue that falls outside the scope of the CISG. ${ }^{82}$ In my opinion, although business practices and usages are expressly made applicable to international sale contracts governed by the CISG pursuant to Article 9, in light of their peculiar features which vary from case to case, such usages and practices can undermine the uniform goals that the CISG purports to achieve. ${ }^{83}$ This may perhaps explain why most of the uniform law conventions that have come into force after the CISG do not include provisions expressly dealing with usages. ${ }^{84}$ Thus, in order to avoid unwanted conflicting interpretations between usages and provisions of the CISG, it is therefore advisable for courts and arbitrators to take a rather cautious approach to usages and practices and to determine the exact force of such rules vis-à-vis the uniform sales law provisions, especially when the application thereof may significantly depart from uniform and predictable rules set out in the CISG. ${ }^{85}$

82. For a discussion on procedural issues and the CISG, see Harry M. Flechtner, The U.N. Sales Convention (CISG) and MCC-Marble Ceramic Center Inc. v. Ceramica Nuova D'Agostino, S.P.A.: The Eleventh Circuit Weighs in on Interpretation, Subjective Intent, Procedural Limits to the Convention's Scope, and the Parol Evidence Rule, 18 J.L. \& Com. 259, 259-87 (1999); Orlandi, supra note 42; La China, La convenzione di Vienna sulla vendita internazionale di diritto uniforme. Profili processuali: la giurisdizione, 44 RivisTA TRIMESTRALE DI DIRITTO E PROCEDURE CIVILE 769-83 (1990).

83. For a contrary view, however, see DiMatteo et al., supra note 35, at 306 ("Some divergence in interpretation is expected and acceptable given the difference in national legal systems and in the very nature of codes. This divergence is expected not only because of the codes multi-jurisdictional application, but also because - like the civil and commercial codes of Europe and the United States ("UCC")- the CISG is an evolving, living law. As such, it provides for the contextual input of the reasonable person, including the recognition of evolving trade usage, in the re-formulation and application of its rules. The benefit of such a dynamic, contextual interpretive methodology is that the code consistently updates its provisions in response to novel cases and new trade usages.").

84. For these remarks, see TORSELLO, supra note 17, at 147 ("Notwithstanding the ever-increasing relevance of usages in the regulation of international trade, reflected in the number of arbitral decisions based upon it, as well as in the creation of international uniform instruments other than Conventions, such as the Incoterms and the Unidroit Principles, international uniform commercial law Conventions seem to be reluctant to enhance the role of usage. This conclusion clearly emerges should one consider that most subsequent Conventions do not even mention usages among the possible sources of law governing the transaction, while the Agency Convention does nothing but reproduce, with the minimal necessary adaptation, the wording of the CISG.").

85. As pointed out by Ferrari, supra note 32, at 335 ("What has been said in respect of Article 9 CISG clearly shows that the rules governing an international contract for the sale of goods are not necessarily only those laid down by the CISG, even where the CISG itself applies. But it also shows that it is important to determine on what grounds one rule applies, as that rule's position in the hierarchy of sources of law for international sales contracts depends on those grounds."). 